\title{
Gathasaptashati: Retelling Intimate history of Ancient Deccan
}

\author{
Dr. Smita Sahgal \\ Associate Professor, Department of History, \\ Lady Shri Ram College (University of Delhi) \\ Lajpat Nagar, New Delhi-110024 \\ India
}

\begin{abstract}
A peep into intimate relations through the study of ancient Indian literature is rather rare. Most of the time Sanskrit literature presents a fairly regulated version of reality, bound by societal norms. On the other hand, Gathasaptashati or Sattasai, composed in Maharashtri Prakrit provides us a rare glimpse into the minds of the populace, especially that of the women who state their intimate desires, anguish and deprivations with a sense of abandon and honesty. This may have become possible as the society of ancient Deccan, where these verses were first composed and compiled, was still not fully stratified or complex. Patriarchy had not yet consolidated and did give women a voice which was preserved in the folklore and recalled now and then subsequently. It may be worth exploring these intimate relations by re-reading some verses and studying the context of their composition.
\end{abstract}

Key words: Gathsaptashati, rendezvous, go-between, traveller, love, eroticism, niti

Most of the ancient Indian literature is in Sanskrit which is assumed to be the language of gods. In reality it has been largely composed by social and literary elites, the Brahmins. Without doubt it is variegated; religious, normative and even narrative in parts. However, its brahmanical (upper caste) veneer does not allow us to read the mind of common people, more so of women. Gathasaptashati not only fills the lacunae but give us a peep into intimate history of the time, something that is difficult to source from Sanskritic literature. What exactly is Gathasapshati and where do we place it in terms of time and locale? What is its language and how is it different from Sanskritic textual expression? What is the focus of the text? What is the social formation of the text and which social class can be predominantly located within it? How does the poetic composition reflect intimate personal relations? Are these relationships socially regulated? These are some of the issues that we will try and answer in our paper.

\section{THE TEXT; AUTHORSHIP, TIME FRAME AND LOCALE}

The Gathasaptashati [seven hundred verse in the Gatha form], is one of the oldest extant anthologies of poetry from Indian subcontinent, containing the earliest examples of secular verse composed in musical arya meter which allows a variety of rhythms within its 'eight bars'. The verses may or may not be sung [1]. However, these certainly remained a part of oral tradition and historical memory of the populace and if not sung were surely recited on many occasions. The compilation of the text has been attributed to the Satavahana king Hala, who lived in the first century $\mathrm{CE}$, but it is reasonable to believe that the text acquired its formal shape sometimes in the early centuries of the Common Era [2]. There has been a difference of opinion among scholars whether Hala had been the author of Gathasaptashati or an earlier text called Gathakosha. Scholars such as D.R.Bhandarkar_ think the two texts are distinct and that Hala was the author of the latter as has been mentioned in the Harshacarita of Banabhatta. However there is another set of scholars including Vasudev.V.Mirashi, who opine that till the ninth century the work was known as a collection or kosh and it was only in the medieval 
period that the nomenclature Gathasaptashati was attributed to it. Most of the scholars believe that out of seven hundred verses, Hala penned down not more than forty-four and the rest were either compilations of folk stories that may have belonged to a much earlier period, possibly the Megalithic phase of the Deccan region, or are representations of other lyrical poets of the age such as Makarandasena, Kumarila, Sriraja and Bhimsvami as has been suggested by later commentators. One commentary lists 261 other poets besides Hala, including six or seven women poets. Bhuvanpala's commentary ascribes 384 names. Modern scholars are, however, doubtful of the accuracy of these names. The existence of many major recensions, according to Winternitz, suggests that the text was very popular by early medieval era in India [3].

\section{Locale}

Hala was probably a king in the Kuntala Janapada, southwest region of former Hyderabad state. A number of Puranas mention his name as the Andhra king in the list of thirty. According to the list, he was the seventeenth Satavahana ruler and ruled for five years sometimes in the first century CE. Other well-known literary references to Hala appear in the Harshacarita of Banabhatta [c.620 CE] and in the Kuvalayamal of Uddyotana [ c.779 CE] The Deccan region appears to be the genesis zone of the Gatha. The geography of the poets and the poetry can be gauged from references to the rivers such as Godavari, Tapti and Murala (in Kerala) and, also Karanja tree of the Western Ghats. Among all the rivers mentioned, Godavari is the most frequently referred river. Godavari river bank emerges as a well frequented spot by the lovers. The Vindhyanchal hill range has also been mentioned in at least six of the verses.

\section{THE CULTURAL TRAJECTORIES OF LANGUAGES; SANSKRIT AND PRAKRIT}

Though it is chiefly known by its Sanskrit name, Gathasaptashati, the anthology is also, known by other Prakrit names, the most common one being Sattasai [the Seven Hundred] and the Ghakoso [A treasury of Gathas]. The language of the text is Maharashtri Prakrit. At this juncture it may be worth evaluating the evolutionary process and growth trajectories of the two genres of languages of early India, Sanskrit and Prakrit.

\section{Progression of Sanskrit}

Stipulating 'two distinct layers in the evolution of Rigveda', noted Sanskritist and historian R.N.Dandekar, worked out a process [samhitakarana] through which stray mantras were made into a Samhita (compiled text) . The Vedic mantras, according to this theory, must have been originally composed in a living dialect, which may be called proto- Vedic, and then these mantras were later on worked upon by hymn makers who purposely used an archaic-looking, priestly, artificial dialect, not their own vernacular[4]. Vedic Sanskrit must have, thus, evolved out of local dialects before assuming its divine exclusiveness. By the beginning of the Common Era, the period that we are dealing with, a new literary genre emerged, quite different from the style of Vedic mantras. It was known as the Kavya. This was poetry, refined, stylized, ornate and elegant. The orality of the Vedic Sanskrit gave way to the written word. As Sheldon Pollock argues what made Kavya historically possible as a cultural practice at all was the written word itself; '..Kavya was a name given to an expressive text that was written down-and that the text was the kind it was precisely because it was written down'[5]. Kavya came to be associated with the court, a discerning audience and the art of masterful reading. Literacy became a commonplace representation in this genre of literature as Kavya came to reflect a cosmopolitan, elitist and at times urban culture.

\section{Evolution of Prakrit}

What of Prakrit? Prakrit also connotes a linguistic process and it was variously etymologized. Some scholars take it to mean the language, 'derived from the prakriti', or the primal language substance, that is Sanskrit', while others understand it as the language, 'existing in or derived from primal linguistic matter that is devoid of grammatical refinement, (Abhinavagupta on 
Natyasastra, 17.3) [6]. What struck Dandin, (the seventh century author of Kavyadarsa) was its regional dimension. It was a plural entity with regional subtypes identified such as Maharashtri (in Deccan), Gaudi (in Bengal), Lati (in Junagarh, Gujarat), Magadhi (in Patliputra, Bihar) etc. Even as these dialects were relatively free of formalized structure, these did come under standardizing pressures of a growing scholarly apparatus and did not remain the dialects of street alone. Prakrit came to stay with the men of letters and also received royal patronage. Mauryan king Ashoka chose Magadhi Prakrit (Pali) as the official language of communication in his inscriptions; Pallavas wrote their early inscriptions in the language and Satavahana rulers made copious use of it.

According to Prakrit grammarians, Maharashtri is the Prakrit par excellence. The very term Prakrit had become to them a metonym for Maharashtri. It is obvious that Prakrits such as Maharashtri must have become a little artificial, as they were different from the spoken languages contemporaneous with them and probably represent vernaculars from some former times [7]. Sanskrit may have influenced the emergence of grammar in Maharashtri Prakrit, but must have also got influenced in the process. Gathasaptashati, reflects the beginnings of early literary systemization. One can accept that Hala's verses were not for the ears of common folk alone; they had courtly listeners too. However, it is also true that during the opening years of the Common Era, Sanskrit became more limited and elitist as it submitted itself to rigours of grammar and became available largely to a literate and trained audience. The cultural and literary sanitization of Prakrit, on the other hand, was not as much forceful and the procedure a good deal unhurried. The language did not completely loose its folk and oral disposition that allowed greater popular input in its lyrical compositions. The idioms preferred suggested rural simplicity and joyful vulgarity that Sanskritists may have refrained from engaging. The Prakrit of Gathasaptashati is different from that of the cave inscriptions of Nasik and Nanaghat. According to Radha Govind Basak this may be due to the fact that the inscriptions were meant for administrative purposes and so may have used a simpler and accessible language while the Prakrit of Gathasaptashati was gradually subjected to evolving rules of grammar [8].

Gathasaptashati is primarily an anthology of love poems suffused with shringara rasa (the erotic love or flavour). The flavour prevails in both its modes; namely union (sambhoga) and separation (vipralambha). Love poems do remind us of the accomplishments of ancient Sanskrit poet Kalidasa; the stateliness of his verse and the elegance of the language that fascinated readers and inspired many scholars. In fact, his poems have given rise to the formation of conventions and rules which have served as guidelines for later works and created a unique niche for the writer in the world of aesthetics. The fact remained Kalidasa's vision was romanticized and imagined with crude reality pushed to margin if it disturbed the aesthetic flow of his thinking frame. However, there could be another genre of love poem; very sensuous and tender, beautiful and inspirational but interspersed with reflections of unsophisticated chores of existence, uncomfortable human relationships and clear voice of resistance. These earthy and sometimes funny renditions abound Gathasaptashati.

A major aspect of the Gatha is its utter conciseness. It has compressed a lot of meaning into very brief poems. Even as these did get encoded in definitive messages with the use of allusion, the verses within the text remain free of rhetorical embellishments and vocabulary remained relatively simple, making these poems, 'clean, sleek transmitters of meaning through dhvani'[9]. Gathas have to be sung or recited and for this reason dhvani or sound (pronunciation, diction, accent, delivery) remained central to its rendition. 


\section{THE SOCIO-ECONOMIC BACKDROP}

Before we look up the core ideas of the Gatha poems, it may be necessary to situate these in a comprehensible social formation which in turn allows us to grasp both the genesis and the flow of these short poems. The society of the Gatha was rural, inhabited by numerous social groups. The chief occupations of the populace appear to be agriculture and cattle rearing. We hear of peasants who make use of ploughs $(769,751)$ and agrarian labour $(776,324)$ on land. It is worth noting that even the name Hala evokes the word for plough, hala. Apart from the use of family labour, we get a sense of labour being employed from outside as well. However, there is no clarity on the kind of wages paid. We are informed that one of the important chores of a wife was to take food (rice) for her husband to the fields. Interestingly, the fields of cotton. rice, pulses and sesamum are often depicted as places of love-making for couples $(165,693,695)$. The reading of Gatha enables one to reconstruct agrarian operations undertaken throughout the year; from the fertility rituals performed at the time of sowing of seeds and yoking of the bulls to the plough (165), to digging and repairing of irrigation canals, and harvesting, threshing and storage of the crops. The staple crops mentioned included rice, barley, pulses, sesame and sugarcane. Among the commercial crop cotton has been mentioned in the text and the contemporary Satavahana and Shaka inscriptions also mention the crop.

Cattle were recognized as a supreme form of wealth. We hear of both cattle keepers and of cattle pens. Daughters often take up the responsibility of looking after the cattle (128) There is a possibility that the cattle were raised both for their use in agrarian chores as well items of food. Hunting continued as chief occupation for some tribal groups. In one of the verses(636), a Pulinda (forest tribe) woman is mentioned, jealous at her husband's lovemaking with another. A certain degree of secondary specialization is evident from references to goldsmith, blacksmith, carpenter, potter, garland-makers, weavers and dyers. What about market and trading activity? Interestingly there are hardly any words connoting trading and commercial activities. Yet the poems are largely about the absent traveller; the way the heroine pines for his return (17), sends a message for an early return and is ecstatic at his return, all allude to movement of men outside the rural confines. We get a sense of the existence of a trading community from allusions to arrangements made for the stay of travellers in the village. Similarly, there are no direct references to a market or a 'hat' but we get hints of negotiations with customers. We get a sense of exchange activity in a verse which states that a man sold his blanket to buy a bull (238). Nagarika or the man of town is often referred to as a street- smartlover by the commentators.

From the text we get an idea of a society in transition from a tribal to a class/ caste-based society. It was not completely brahmanized but the process had begun [10]. There is no clear mention of any caste but some kind of social stratification is evident with references to king, amatya and courtiers who appear to be among the favoured group. Peasants also occupied a significant place and so did the physicians who have been repeatedly mentioned, followed by artisans of different types. It is possible that the Pulinda and other forest tribes were among the marginal groups.

\section{CORE THEME: LOVE AND EROTICISM}

It has been assumed by some commentators that Prakrit poetry conveys secrets of Kamashastra[11]. Within the opening verses a question is asked, 'Why do they not feel ashamed to discuss the philosophy of love, who do not know how to read or hear nectar like Prakrit poetry'? (2) In fact, Gathsaptshati offers a more realistic counterpart to the theoretical treatise on love, the Kamasutra, which rests in an urbane cosmopolitan milieu. The environment in the text, as mentioned earlier, is largely rural, untouched by urbane sophistication but full of erotic allusions. The voice often appears to be that of women. We may call it essentially a woman's book, a compendium of her signs, utterances, and silences and, 
therefore, loaded in one direction, Women seemed to have played both the roles; their own and that of men. This could be possible if the large portions of the text had their genesis in the village milieu and preserved in the folk lore of which women were the chief transmitters. The style of the poetry is very conversational and all commentators also feel that each verse makes its full point only if it is addressed by one to another. The frequent terms used by commentators are nayaka for male speaker and nayika for female and this means that they were fully aware of the hero-heroin division in the poetic narrative, seen in the Natyashastra as well. But clearly the focus is on female characters, elaborate subdivisions of male characters are often missing from commentator's analysis [12].

The Gatha has many subthemes: sometimes it's direct or oblique references to rendezvous spots, at other times the pain of separation, still other very strong erotic desire. The most interesting verses are the ones that allude to responses of women to social prescriptions; their resistance to social accountability. We can trace some moods from the following verses;

\section{Rendezvous spots}

Reference to Summer season

O Summer! in which Rendezvous (samkea) is easy to obtain

Because of drying up of ponds

Because of leaflessness of Bowers

Touch stone of Golden Happiness

Never end! (628)

There is the fear of loss of another rendezvous spot as rice harvest approaches

Every day Anxiety increased, The end of meeting place,

With face slightly pale and downcast,

The girl who guards rice, dries up,

Along with rice (693)

There can be numerous rendezvous spots; fields, a piece of enclosed ground, ruined temple, gobetween's house, bank of river, garden (malapancha) and so on described by protagonists in the poems and dwelt upon by later commentators [13].

\section{Resistance to social prescription}

Tight lads in fields, A month in spring,

A cuss for husband, Liquor in the rack,

And she young, free hearted: Asking her to be faithful

Is asking her to die. (197)

Or the one in which the wife with the assistance of her friends reaches her lover

'A scorpion has bitten her', they cried,

And as she thrashed about,

Her shrewd friends in her husband's presence

Rushed her to her physician lover. (237)

\section{Familial teasing}

There are references to wife waiting for her absent husband/ traveller. There are also allusions to their love making and to their estrangement. In one verse the husband begs for forgiveness but the wife brings in the child and laughs after remembering a love act,

The remorseful husband, Fallen at her feet

Their little boy Climbs onto his back

And sullen wife Laughing. (11)

Or the one in which they want to get over troubles

For our quarrels, Lets appoint another night,

The bright one slips by (466) 


\section{Demanding nayika (heroin):}

Bookish love making, Is soon repetitive:

It's the improvised style, Wins my heart. (274)

\section{Jesting Relationship with Brother-in-law (devara)}

At least ten verses are closely concerned with the relationship between a young wife and her brother-in- law, devara in a jesting relationship. A woman who has been in love with her brother-in-law but has not been able to decide a place of assignation, encourages him to visit her father's place as it could be safe for a rendezvous.

Stop lying brother-in-law

You have not seen my village, Nor the winding Murula,

With many bends, many canebrakes (876)

Teasing the Brother-in-law

Ah, brother-in-law, turn away from the night sky;

Rows of crescent moons, Rise in your wife's armpits

There are differences of details in the verses: for example in a verse, she shows physical signs of having engaged in love play with him, while in another, she shows jealousy because he has gone to make love with another girl, village headman's daughter who has turned the village into an unblinking god (593), in yet another verse, she points to a painting on the house wall of Rama and Lakshmana in order to (seriously or otherwise) warn him of making love to her etc. These instances appear to be close to the jesting relationship of modern times.

\section{Polygyny and tension among wives/paramours}

In a verse the wife is pained by husband's preference for another woman:

Mother! were he abroad, I'd bear the separation

Waiting for him, but to live in separate houses

In the same village, Is worse than death. (43)

A wife to a co-wife:

Proud, aren't you, to display, The beauty streaks

Your husband painted on your breasts?

When I stood before mine, His hands lost all Control over the line. (830)

In another verse the wife, (pativrata) speaks to her aunt of the satisfaction at destroying the meeting site where her husband would make love to another woman.

Paternal Aunt! The Leaves of the Village Fig tree!

White in colour, Struck by Winds,

Fall together with the heart of white-faced unfaithful woman (295)

Despair at husband's marrying again

The firm breast of his new wife

Through hollow cheeks the old one sighs

Interestingly we also come across a reference to a woman/ wife recommending multiple sexual existence for her husband so that he would be able to discern variety, enjoy the difference and not get used to just one type of love making.

There are numerous references to wanton women/prostitutes as well but unlike the Kamasutra, whose context is urban post-Gupta period, the background reflected in the verses is clearly rural. There are verses that allude to prostitutes alluring young men of the village and the mothers of prostitutes training them to win over prospective customers. The institution of prostitution was, however, not without its critics and was often held responsible for declining social values. 


\section{SUBTLE THEME: MORAL INSTRUCTIONS (NITI)}

Was the function of poetry only to awaken its audience to genuine aesthetic experience or also let it provide moral instructions (vyutpatti)? J.M.Masson would want us to believe so [14]. In the words of Kunataka, tenth century Kashmir Sanskrit poetician and literary theorist who is remembered for his work Vakroktijivitam, all primary sentient beings described in the poetry should be so presented in their actions as to serve as models for others in achievement of four fold model in life. Poetry, in other words had a moral and didactic purpose. It is amazing that how often even in this group of short poems, dominated by the theme of love and erotica, moral instructions seep their way through. We read the flow of niti. By niti we do not mean political skill but knowledge that enables the wise to know other's inner state (408). The emphasis is on inference of reality from outward signs and making use of this knowledge in a constructive way. So, we come across a reference to a girl informing another one of how to recognize a deceitful woman (166) or a dejected man stating that one should never trust a woman. The implication in one of the verses is that one must strive to help others as even a peasant is intent on helping others (695). A nagarika speaks to a companion of how a rogue understands secret things. Similarly, a woman disguises to expose the superficiality of another woman [15]. Such verses spill across to send subtle messages about what the poets of the verses deemed as moral and ethical for their social set up.

Overall what abounds the text is description of interpersonal relationships between husband and wife, wife and co-wife, wife and brother-in-law, daughter-in-law and her mother-in-law, amongst friends and so on. There is a love-hate relationship with mother-in-law. Sometimes she is called 'rigorous' (875) while at other times she is depicted as sensitive to her daughterin-law's plight who keeps waiting for the absent traveller/ husband to return. 'When she bends to touch, her mother-in-law's feet and two bangles slip from her hand, tears come in the cold woman's eyes' (493). The society of the Gatha was gradually becoming patriarchal. The unmarried girl is supposedly kept under close watch to guard her reputation. She needs considerable ingenuity and daring to make secret rendezvous with her lover in fields and forests A good wife is advised to get up early in the morning, take bath and do household chores. She is expected to become sensitive to the needs of each member, help her husband in his agrarian work, and take up the religious responsibilities such as making donations or giving food to bhikshu. Sometimes this becomes an occasion for starting a liaison. 'While the Bhikshu viewed her navel and she his handsome face, Crow licked clean both ladle and alms bowl (162). The social set up of Gatha, however, was still not a strong caste-based patriarchy. Some women are shown to be fond of liquor and many find ways to resist the social imposition about their sexuality (197). In one verse the daughter- in- law threatens her mother -in-law that if the latter were to make public her secret meetings with her lover, she ,too, would spill beans about her affair (670).

Gathasaptashati holds immense possibility of exploration across numerous streams such as history, literature, linguistics and even human psychology. But its real beauty lay in bringing out intimate emotions of the populace, still largely unfettered by social regulations and normative traditions. In fact, the poetry suggests a stage of transition. The process had barely begun and had not really muffled the voice of women who discuss their intimate desires with friends and lovers. The verses are both simple and layered and open to scrutiny of a trained eye. There is the scope of studying the evolution of language, literary styles, physical environment and historical contexts but essentially the Gatha is a compendium of love poems; an expression of very basic human sentiments put across cogently without any artifice.

Citations 
[1] Peter Khorche and Herman Tieken ed and trans., Poems on life and love in Ancient India: Hala Sattasai, Albany: SUNY, 2009, p.1.

[2] A.K.Mehrotra, The Absent Traveller; Prakrit Love and Poetry from the Gathasaptasati of Satavahana Hala, Delhi: Ravi Dayal Publisher, 1991, p.ix.

[3] Moriz Winternitz, History of Indian Literature, Delhi: Motilal Banarsidass, 1963, pp. 114116.

[4] R.N.Dandekar, Proceedings of Indian History Congress, Bombay, 1947, pp.49-55.

[5] Sheldon Pollock, The Language of Gods in the World of Man: Sanskrit Culture and Power in Premodern India, Ranikhet: Permanent Black, 2006, p.83.

[6] Ibid, p.91.

[7] Martha Anne Selby, Afterword, in A.K.Mehrotra's Absent Traveller, p.72.

[8] Radhagovind Basak, The Prakrit Gatha Saptasati, Compiled by Satavahana king Hala, Calcutta:Asiatic Society, 2010, Intro.

[9] Martha Anne Selby, op cit.

[10] Brahmanization is the process by which many tribal/egalitarian societies are converted into caste-based complex set up with brahmins and kshatriyas as the ruling elite. This is both a social and a political process.

[11] Paul Dandas, Sattsai and its Commentators, Taurino, 1985, p.37.

[12] For details, see, Paul Dandas, op cit, p.10

[13] Paul Dandas, op cit, p.31.

[14] J.M.Masson, 'Truth or Falsity in Poetry', Annals of the Bhandarkar Oriental Institute, Vol.60.no.1,1979, p.225.

[15] Paul Daundas, op cit, pp. 36-37.

\section{BIBLIOGRAPHY}

Basak, Radha Govind, ed. The Prakrit Gatha Saptasati, Compiled by Satavahana king Hala, Asiatic Society, 2010.

Dandekar, R.N., Proceedings of Indian History Congress, Bombay, 1947.

Dandas, Paul, Sattsai and its Commentators, Taurino, 1985.

Khorche, Peter and Herman Tieken ed and trans. Poems on life and love in Ancient India: Hala Sattasai, Albany: SUNY, 2009.

Masson, J.M. 'Truth or Falsity in Poetry', Annals of the Bhandarkar Oriental Institute, Vol.60.no.1,1979, pp.225228.

Mehrotra, A.K., The Absent Traveller; Prakrit Love and Poetry from the Gathasaptasati of Satavahana Hala, Delhi: Ravi Dayal Publisher, 1991.

Pollock,Sheldon, The Language of Gods in the World of Man: Sanskrit Culture and Power in Premodern India, Ranikhet, Permanent Black, 2006.

Winternitz, M., History of Indian Literature, 3 vols. Delhi: Motilal Banarsidass, 1963. 